\title{
Lessons from COVID 19 - What the Virus has Taught Us
}

\author{
COVID-19'dan Dersler - Virüs Bize Ne Öğretti
}

\section{Obiyathulla Ismath BACHA (D) 0000-0001-8564-3248}

International Centre for Education in Islamic Finance, Kuala Lumpur, Malaysia

\section{Corresponding Author Sorumlu Yazar \\ Obiyathulla Ismath BACHA obiya@inceif.org}

Received / Geliş Tarihi : 15.01.2021 Accepted / Kabul Tarihi : 14.02.2021 Available Online /

Çevrimiçi Yayın Tarihi : 04.03.2021

\begin{abstract}
The traditional view, of a linear relationship between the development levels of countries and their ability to deal with problems has been completely changed with the coronavirus disease 2019 (COVID-19) pandemic. The countries hit hardest by the pandemic have been the so called developed ones of Western Europe and the USA. Equating development to mega cities has been shown to be misplaced. The pandemic has spread fastest in crowded cities such as New York and Los Angeles. Aside from overpopulated cities, ignoring the environment and the need for healthy living conditions are other important reasons for their failure to control the epidemic. Yet, countries such as Taiwan, South Korea and Japan have had very low infection rates relatively, even though most of their populations live in large urban centers. The difference may be due to the extensive practice of using face masks in these countries. The need to emphasize and rely on science and technology to solve the problems of humankind is among the key lessons that the pandemic has taught us. A final lesson the virus has taught us, is that regardless of which country we live in, our well-being and destinies are closely indeed intertwined. A health care crisis anywhere in the world can affect us all and very quickly too.

Keywords: COVID-19 pandemic; developed countries; measures.
\end{abstract}

ÖZ

Koronavirüs hastalığı 2019 (coronavirus disease 2019, COVID-19) pandemisi ile birlikte, ülkelerin gelişmişlik düzeyleri ile karşılaştıkları sorunlarla baş etme konusundaki performansları arasında doğrusal bir ilişki kuran geleneksel bakış kökten değişmiştir. Beklenilenin aksine, pandemiden en fazla etkilenen ülkeler Batı Avrupa ülkeleri ile ABD gibi gelişmiş ülkeler olmuşlardır. Mega kentlerde de benzer olumsuz tablo görülmüş, pandemi New York ve Los Angeles gibi büyük kentlerde en yüksek yayılma düzeyine sahip olmuştur. Kentlerin aşırı nüfuslu olmaları bir yana, kaliteli çevre ve yaşam koşullarının büyük kentlerde ihmal edilmesi bu kentlerde hastalığın yayılım hızının daha yüksek olmasına yol açan diğer faktörler olmuştur. Öte yandan, Tayvan, Güney Kore ve Japonya gibi ülkelerin yüksek nüfusa sahip olan kentlerinde, diğer gelişmiş ülkelerin büyük kentlerinde hastalığın hızlı yayılım sorunu gözlenmemiştir. Bu farklılık, bu ülkelerde toplumun temizlik ve maske kullanımı kurallarına uyma konusunda çok daha yüksek hassasiyet göstermesi ile ilgili olabilir. Modern zamanlarda akla gelmeyecek olan bu pandeminin bizlere öğrettiği en önemli konulardan birisi hiç kuşkusu insanoğlunun karşılaştığ 1 bu sorunlara karşı bilim ve teknolojinin bu sorunlarla mücadelede hayati öneme sahip olduğudur. Virüsün öğrettiği bir diğer şey de ne düzeyde gelişmiş bir ülkede yaşadığımıza bağlı olmaksızın sağlık yönünden iyi durumda olmak ve kaderin birbirinden bağımsız olmadığıdır. Ayrıca, dünyanın bir köșesinde yaşanan bir sağlık sorununun aslında dünyanın geri kalan tamamını da ilgilendirmesi gereken bir sorun olduğu bu sağlık krizi ile tescillenmiştir.

Anahtar kelimeler: COVID-19 pandemisi; gelişmiş ülkeler; tedbirler. 
A virus far too small for the naked eye has brought the world to a screeching halt. Lockdowns, something unheard of previously, became a common feature across many countries in early 2020. Subsequently, the world witnessed a series of lockdowns of different duration and intensity. Yet, the virus shows little sign of abating. The trillions spent by advanced nations on defense budgets, seemingly to protect their citizens lives and their economies has had zero effect in this war. Ironically, even the billions invested in biological warfare defense has meant nothing. Across the world, even in the most developed of countries, death and destruction has been rampant, the world just passed the 2 million mark for deaths and the global economy is in ruins. Like the kid who exposed the emperor to have had no clothes, the virus has laid bare the stupidity if not the misplaced priorities of mankind.

Governments, as they always have with crises, have responded with stimulus packages. Only this time the packages have been very much larger. There is a good reason for this unprecedented size, the world was already sitting on a tinder box of debt even before the virus came along. Thanks to the addiction of central banks particularly the US Fed, to monetary stimulus, governments, corporations and even households are up to their necks in debt. The numbers are staggering. Just before the pandemic, at end 2019, total global debt, according to Washington based IIF was about US\$ 255 trillion while total global GDP was US\$ 86 trillion. Thus, global debt to GDP is a massive $300 \%$. These debt numbers have continued to grow. If the first lesson the virus taught us was the futility of spending on military hardware for safety, the second maybe the irrationality of dependence on monetary stimulus. More than the virus and health issues, governments and central banks are now worried that any number of events could trigger an avalanche from the mountain of debt they have created. So, even if the vaccine enables us to beat the virus and bring it under control, managing the potential economic fallout promises to be the bigger battle.

The fact that countries deemed the most developed and advanced have been among the hardest hit by the virus, the US, UK and Western Europe points to the fallacy of "development" as we now know it to be. If the aspiration for development means mega cities and tall gleaming towers with very high human densities, it is misplaced. That New York and Los Angeles have been the hardest hit within the US shows the need for less human concentration. The obvious lesson here is that; development has to be more diffused and better balanced environmentally with emphasis on green investment. Our cities may have to be redesigned with less overcrowding, much lower density ratios enabling better hygiene and living standards. The virus has spread exponentially where population density is highest.

The need to change our social and cultural behavior is another lesson from the virus. Much of our social norms entail closeness. Praying in congregations, shaking hands, hugging, travelling in jam packed transportation and meetings/conferences involving hundreds if not thousands within closed confined spaces, must all be rethought. Humans are social beings, we cannot live in isolation, yet, the pandemic has taught us that where interaction is necessary hygiene and personal protection is necessary. It is not by accident that countries such as Taiwan have had the lowest infection rate. Taiwan together with South Korea and Japan are societies where the use of facial masks is common practice. All three countries are among those that have had the lowest infection rates, as per cent of population. This despite the fact that most of their populations live in large urban centers. Governments should encourage the continued use of masks in public spaces especially where social distancing may be difficult. This should be one good social habit that comes out of the pandemic but outlives it.

Until last year, the budget allocation for health care was not priority for most governments. If anything, reductions in health care spending could easily go unnoticed in most government budgets. Governments in many developing countries were happy to privatize as much of their health care system as possible. This slow erosion in health care funding over years, meant that capacity constraints were reached very quickly. Not only were public health care systems of most countries understaffed but physical facilities too were inadequate. The years of underinvestment in public health facilities and services became apparent very quickly into the crisis. It is fortunate that unlike the other variants of the coronavirus like severe acute respiratory syndrome (SARS), coronavirus disease 2019 (COVID-19) had a much lower mortality rate. The lesson here is that not only must public healthcare be prioritized, there also has to be a quick reallocation of resources away from items like military to health care. The flaw in depending on the private sector to provide a social good at a time of a health emergency is obvious. The pandemic showed health care to be far too important to be left largely to the private sector.

As the pandemic raged, governments were forced to spend billions in emergency unbudgeted funds. This was money not previously intended for health care but had to be, in order to meet the emergency. Until recently, all increases in government budgetary allocations were thought off as trade-offs. A cost-benefit framework being used in the evaluation. The pandemic has shown that there is a huge social cost, what economists would call an externality at work here. The trade-offs in deciding on allocations to health care has changed massively. The pandemic has shown that the risk of under allocation is far greater than previously thought.

The need to emphasize and rely on science and technology to solve the problems of humankind is yet another lesson that the pandemic has taught us. Even if it is still early, the vaccine has been a game changer. Science has indeed delivered and in a timely fashion. The challenge is now for organizational leadership and logistics to deliver the vaccine to a critical mass of the population. It is clear that economic revival of countries now depends on how quickly sufficient portions of their population are vaccinated. The efforts that went into vaccine development, is a lesson in itself, initiatives such as Operation Warp Speed show how focusing attention and giving resources to the best and brightest can get us the desired results. Operation Warp Speed produced more than one vaccine and in record time. Though less known, it is obvious that countries like China and Russia which have also produced vaccines would have had their own operational initiatives. The success of these initiatives provides lessons for how future crises, health or otherwise should be handled. 
A final and perhaps the most important lesson the virus has taught us, is how closely our well-being and destinies are intertwined. Regardless of where we live, a health care crisis anywhere in the world can affect us and very quickly too. The world is but one village and there is no way to detach one's country or community from others. Let's hope this one lesson does finally sink in.

Ethics Committee Approval: Since our study was a review, ethics committee approval was not required.

Conflict of Interest: None declared by the authors.

Financial Disclosure: None declared by the authors.

Acknowledgements: None declared by the authors.

Author Contributions: Idea/Concept: OIB, Design: OIB, Data Collection/Processing: OIB, Analysis/Interpretation: OIB, Literature Review: OIB, Drafting/Writing: OIB, Critical Review: OIB.

\section{REFERENCES}

1. iif.com [Internet]. Institute of International Finance. Upcoming Events. [Cited: 2021 Feb 3]. Available from: https://www.iif.com/Events/Upcoming-Events.

2. imf.org [Internet]. International Monetary Fund. The IMF and COVID-19 (Coronavirus). [Cited: $2021 \mathrm{Feb}$ 3]. Available from: https://www.imf.org/en/Topics/ imf-and-covid19.

3. worldbank.org [Internet]. The World Bank. The World Bank Group's Response to the COVID-19 (coronavirus) Pandemic. [Cited: 2021 Feb 3]. Available from: https://www.worldbank.org/en/whowe-are/news/coronavirus-covid19.

4. ourworldindata.org [Internet]. Our World in Data. Coronavirus (COVID-19) Vaccinations. [Cited: 2021 Feb 3]. Available from: https://ourworldindata.org/ covid-vaccinations.

5. cdc.gov [Internet]. Centers for Disease Control and Prevention. COVID-19 Vaccine: Helps protect you from getting COVID-19. [Cited: 2021 Feb 3]. Available from: https://www.cdc.gov/coronavirus/ 2019-ncov/vaccines/index.html. 